\title{
Determination of reproductive span through morpho-histological studies on the ovaries of captive brown bears (Ursus arctos) - a short communication
}

\section{Slaven Reljić1*, Agnieszka Sergiel², Nikica Prvanović Babić ${ }^{3}$, Ana Beck Snježana Kužir ${ }^{5}$, Berislav Radišić ${ }^{6}$, Robert Maślak ${ }^{7}$, Michal Bednarski ${ }^{8}$, Tomasz Piasecki ${ }^{8}$, Doroteja Huber ${ }^{4}$, and Đuro Huber ${ }^{1}$}

${ }^{1}$ Department of Veterinary Biology, Faculty of Veterinary Medicine, University of Zagreb, Zagreb, Croatia

${ }^{2}$ Department of Wildlife Conservation, Institute of Nature Conservation of Polish Academy of Sciences, Krakow, Poland

${ }^{3}$ Clinic for Obstetrics and Reproduction, Faculty of Veterinary Medicine, University of Zagreb, Zagreb, Croatia ${ }^{4}$ Department of Veterinary Pathology, Faculty of Veterinary Medicine, University of Zagreb, Zagreb, Croatia

${ }^{5}$ Department of Anatomy, Histology and Embriology, Faculty of Veterinary Medicine, University of Zagreb, Zagreb, Croatia

${ }^{6}$ Clinic for Surgery, Orthopaedics and Ophthalmology, Faculty of Veterinary Medicine, University of Zagreb, Zagreb, Croatia

${ }^{7}$ Department of Evolutionary Biology and Conservation of Vertebrates, Institute of Environmental Biology, University of Wroclaw, Wroclaw, Poland

${ }^{8}$ Department of Epizootiology and Clinic of Birds and Exotic Animals, Faculty of Veterinary Medicine, Wroclaw University of Environmental and Life Sciences, Wroclaw, Poland

RELJIĆ, S., A. SERGIEL, N. PRVANOVIĆ BABIĆ, A. BECK, S. KUŽIR, B. RADIŚIĆ, R. MAŚLAK, M. BEDNARSKI, T. PIASECKI, D. HUBER, Đ. HUBER: Determination of reproductive span through morpho-histological studies on the ovaries of captive brown bears (Ursus arctos) - a short communication. Vet. arhiv 89, 233-246, 2019.

\section{ABSTRACT}

The study aimed to determine reproductive span by investigation of the ovarian structures in young and elderly captive brown bear females (Ursus arctos). The ovaries of two 2-year-old females were obtained by ovariectomy and during the necropsies of 31 and 36 year old individuals. All the obtained ovaries were examined macroscopically and histologically. Histological examination of the ovaries of young animals (2+ years) revealed the presence of primordial, primary, secondary and tertiary follicles within the ovarian

*Corresponding author:

Slaven Reljić, DVM, PhD Candidate, Biology Department, Faculty of Veterinary Medicine, University of Zagreb, Heinzelova 55, 10000 Zagreb, Croatia, Phone: +385 91584 6114; Fax: +385 12390 158; E-mail: sreljic@vef.hr 


\section{S. Reljić et al.: Reproductive span in captive brown bears}

cortex. One ovary showed a mature corpus luteum, indicating recent ovulation, what is, to our knowledge, the first histological proof of the earliest age of ovulation recorded for captive brown bears. Ovarian atrophy accompanied by the development of multiple cystic subsurface epithelial structures (SES) in the case of the old bears in this study indicates that the ovaries of brown bears share similar degenerative and proliferative patterns with domestic canids. The oldest female had records of successful births at the ages of 26 and 28 years. Both recorded birth events represent one of the latest confirmed occurrences of ovulation, conception and birth amongst brown bears.

Key words: reproduction; puberty; ovulation; corpus luteum; post-reproductive phase

\section{Introduction}

Reproductive span in females, i.e. the age of the earliest and latest reproduction, is one of the most important parameters influencing population dynamics in free-living species (SCHWARTZ et al., 2003a; KNOTT et al., 2014). Opportunities to effectively investigate reproductive span in free-living brown bears are scarce, and efforts for proper monitoring need to be well designed and long-lasting. However, some opportunistic evidence of reproductive span in females has been recorded. TSUBOTA et al. (1989) described a case of one corpus albicans in a 2-year-old free-living female brown bear from the Japanese island of Hokkaido. FRKOVIC et al. (2001) presented the earliest reproduction in one radio-collared 3-year-old female brown bear in Croatia that gave birth to two cubs. A series of indirect but verified information about two females' birth year in an introduced population in Austria and the age of their first litters, suggested that free-living female brown bears were able to have a litter at the age of three years (ZEDROSSER et al., 2004).

Puberty in mammals is the process of acquiring reproductive competence. The onset of puberty depends upon the ability of specific hypothalamic neurons to produce the gonadotropin-releasing hormone $(\mathrm{GnRH})$ in sufficient quantities to promote and support gametogenesis. In female animals, the first direct sign of reproductive activity is the production of ova (YAMANAKA et al., 2011). Development of hypothalamic GnRH neurons is influenced by the development of threshold body size, exposure to a variety of environmental and social cues, and the genetics of the animal. The age at which puberty is acquired varies among and within species, but a current hypothesis contends that the females must develop a certain body size in order to enter puberty (SENGER, 2015). Several external factors also modulate the timing of puberty, and these vary significantly among species. Those factors include the season during which the animal is born (small and wild ruminants), the presence or absence of the opposite sex during the prepubertal period (swine and cattle) and the density of the group or herd within the same sex (wild and domestic swine) (NOAKES, 2009).

Although the mechanism of puberty in bears is still not entirely clear (WHITE et al., 2005; TSUBOTA et al., 2008), it should follow some of the patterns already described for 
other species of wild mammals. In order to study the mechanism involved, it is crucial to determine the timing of the first ovulation and at the same time analyse endogenous and exogenous stimuli present. In mammals, we can distinguish four developmental stages of the follicles within the ovarian cortex: primordial, primary, secondary and tertiary (Graff) follicles (CARNEVALE, 2008). The Graff follicle contains ova that in bears (and some other species) are released during ovulation induced by coitus, so-called post-coital ovulation (BOONE et al., 1998; BOONE et al., 2004).

Another important aspect of reproduction is the post-reproductive phase, the period of life when an animal is incapable of reproduction. In most animal species the postreproductive phase of life represents an unproportionally short or even missing segment of their entire life span (WILLIAMS, 1957; REZNICK et al., 2006; NISHIDA et al., 2003; PECCEI, 2001). Evolutionary pressure selects towards maximising reproductive effort and success (CHARNOV, 2004; KIRKWOOD and ROSE, 1991) and minimising post-reproductive life. Reproductive senescence has been reported in many longliving species, including humans, non-human primates, horses and other ungulates and carnivores (BERGA, 2008; CARNEVALE, 2008; KIRBY et al., 2009).

In captivity, individuals of a certain number of animal species may live longer than in the natural environment and thus prolong both the reproductive and the post-reproductive phase. The maximum life span recorded for captive brown bears is 50 years (SCHWARTZ et al., 2003a). In a natural habitat, adult bears live mainly solitarily, and distances between individuals are considerable, so direct encounters are mostly related to their reproductive status (STIRLING and DEROCHER, 1990; DAHLE and SWENSON, 2003). In the areas where food is seasonally abundant (e.g. salmon streams) or concentrated in one place (e.g. garbage dumps or carcasses), bears may form short-term aggregations and show tolerance for one another. These situations seem to be restricted to the non-breeding season when the blood levels of sex hormones affecting aggressive behaviour are low. However, females with cubs of the current year, facing possible infanticide, generally avoid salmon stream aggregations (EGBERT and STOKES, 1974; HERRERO, 1983; BEN-DAVID et al., 2004; TEISBERG et al., 2014). In captivity, bears are often kept in a combination of conspecifics that would rarely or never occur in nature and certainly would not last as such for an extended period of life (KOENE, 1996).

In order to investigate the earliest and latest signs of ovarian activity in captive brown bear females and potential successful reproduction, a preliminary morpho-histological study was performed on ovaries obtained from two young and two senescent individuals. For a better understanding of the reproductive capacity of captive brown bear females, the histological findings from the ovaries were compared to all the available life-history data concerning housing, life span, mating habits and successful reproductions. 


\section{Materials and methods}

Animals, housing and reproductive history. Female No. 1 was captive born in 2007 in Zagreb Zoo and was housed in the bear sanctuary at Kuterevo (Croatia, $44^{\circ} 49^{\prime} \mathrm{N} 15^{\circ} 08^{\prime} \mathrm{E}$ ) from the age of 10.5 months in the continuous presence of a male sibling.

Female No. 2 was wild born and orphaned in 2010 when she was moved to the bear sanctuary at Kuterevo at the age of 8 months (September 2010), and since May 2011, she has been kept with an unrelated uncastrated male of the same age.

Females No. 1 and 2 were ovariectomized as a routine procedure for sanctuary bears (RADISIC et al., 2010) at the age of 2 years and 2 months, and 2 years and 4 months, respectively, and the ovaries were preserved for examination.

Female No. 3 was born captive in 1963 in Frankfurt Zoo in Germany by the parents genetically originating from Kodiak Island, Alaska, USA. She was kept in Zagreb Zoo (Croatia, $45^{\circ} 49^{\prime} \mathrm{N} 16^{\circ} 01^{\prime} \mathrm{E}$ ) with a sibling male who died when she was at the age of 21 years. During 21 years of cohabitation, no reproduction was recorded. Female No. 3 was euthanised ten years later at the age of 31 due to severe arthritis.

Female No. 4 was born captive in 1975 in Łódź Zoo and transferred to Braniewo Zoo (north-eastern Poland, $54^{\circ} 23^{\prime} \mathrm{N} 19^{\circ} 50^{\prime} \mathrm{E}$ ) as a cub. She cohabitated with an unrelated male during two reproductive seasons for breeding purposes. She gave birth to a female cub in 2001, at the age of 26, and to a male cub in 2003, at the age of 28 . There is no earlier history available of her pregnancies. Since 2003 she has been kept with a male offspring in the same enclosure. Mating attempts were recorded but with no results thereafter. In February 2011, at the age of 36, the female was euthanised due to her deteriorating clinical condition without response to therapy.

The examinations of the captive brown bears were performed when the animals were immobilised for reasons including veterinary monitoring, health intervention or due to captive animal management reasons, including euthanasia when necessary. All the methods applied were in accordance with the animal ethics and welfare requirements and standards.

Macroscopic and histological analysis of the ovaries. The ovaries were macroscopically photographed (ZEISS AxioCam ERc 5s camera; ZEISS, Göttingen, Germany) and examined for possible evidence of ovarian activity. For further histopathological examination, seven ovaries from four females (the exception was female No. 1 with only one ovary obtained) were submitted to the histopathology lab of the Faculty of Veterinary Medicine in Zagreb. The ovaries were fixed in 10\% neutral, buffered formalin for 24-48 hours, routinely dehydrated, embedded in paraffin, cut to a thickness of $5 \mu \mathrm{m}$ and stained with hematoxylin and eosin $(\mathrm{H} \& \mathrm{E})$. In reproductively active females, the presence of all developmental stages of follicles, as a sign of ovarian activity, and the presence of any stage of corpora (albicans, luteum, rubra), as proof of ovulation, were histologically 
evaluated. In the older females, senescence-related alterations such as fibrosis and cysts were investigated to determine signs of ovarian inactivity.

\section{Results}

Histology of ovaries. Only one ovary was examined from female No. 1. We cannot know the effects of missing ovary status on the present ovary findings. The ovaries of both the 2-year-old females had the characteristics of typical ovaries of healthy and reproductively mature young females.

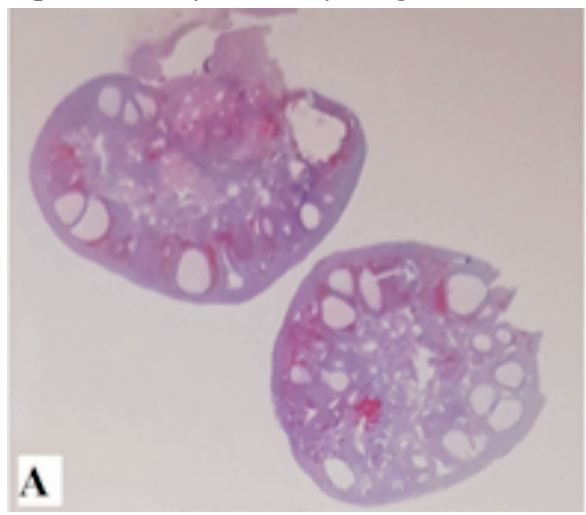

Fig. 1A. Macroscopic picture of transversal cuts through the ovaries of the female No. 2, dehydrated and stained by hematoxylin and eosin (H\&E), measuring $13 \times 10 \mathrm{~mm}$ and 11 $\times 6 \mathrm{~mm}$. The cortex contains multiple grossly visible follicles measuring from 1 to $3 \mathrm{~mm}$ in diameter.

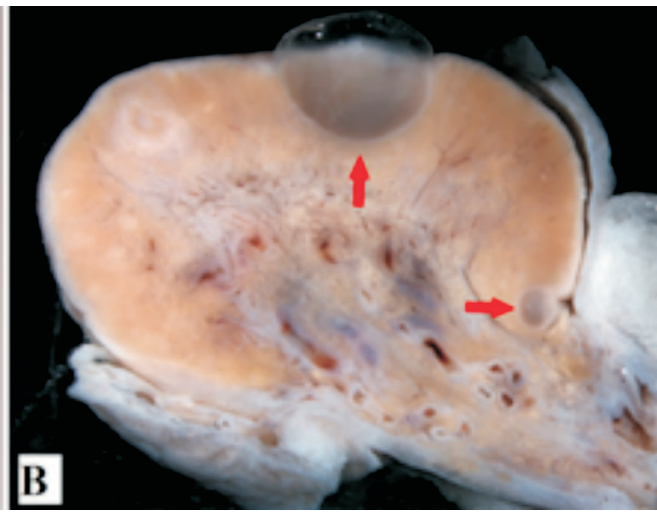

Fig. 1B. Macroscopic photo of a transverse cut through the left ovary of female No. 4, after 24 hours of fixation in formalin, measuring $3.3 \times$ $2.7 \mathrm{~cm}$. The cortex contains two fluid-filled cysts measuring $10 \times 8 \mathrm{~mm}$ and $2.6 \times 2.4 \mathrm{~mm}$ (arrows).

The cortex showed follicles in all developmental stages: primordial, primary, secondary and tertiary (Fig. 1A and 2A). One ovary of female No. 2 revealed a mature corpus luteum (Fig. 2B). Upon comparison of the findings from the ovaries in females No. 1 and No. 2, the ovaries of female No. 2 contained more connective tissue in the cortex, fewer follicles in all developmental stages, and more atretic follicles.

The older females, at the ages of 31 (female No. 3) and 36 years (female No. 4), both had inactive ovaries. Histology revealed severe fibrosis of the cortex and medulla of both females' ovaries (Fig. 3A). The cortex contained unilateral (female No. 4) and bilateral (female No. 3), multiple cysts, 9 to $24 \mathrm{~mm}$ in diameter, filled with eosinophilic, proteinaceous fluid and lined by flat or cubic epithelial cells corresponding to the subsurface epithelial structure (SES) cysts described in the ovaries of dogs (SCHLAFER and FOSTER, 2016) (Fig. 1B and 3B). 


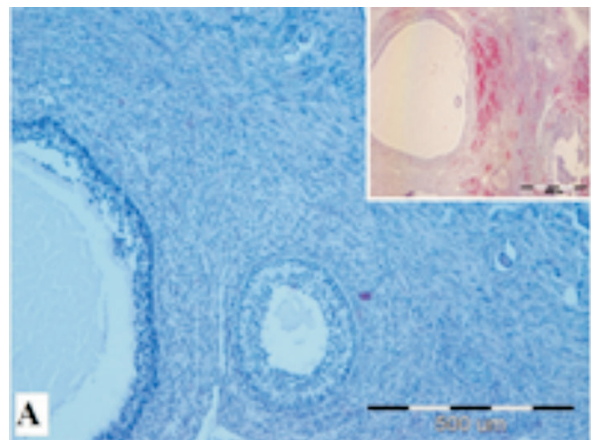

Fig. 2A. Cortex of the ovary from female No. 1 , containing multiple follicles. Scale bar $=500$ $\mu \mathrm{m}$. H\&E, objective magnification $\times 10$. Inset: Tertiary follicle in the cortex of the left ovary of female No. 2. Scale bar: $1000 \mu \mathrm{m} ; \mathrm{H} \& \mathrm{E} ; \times 4$.

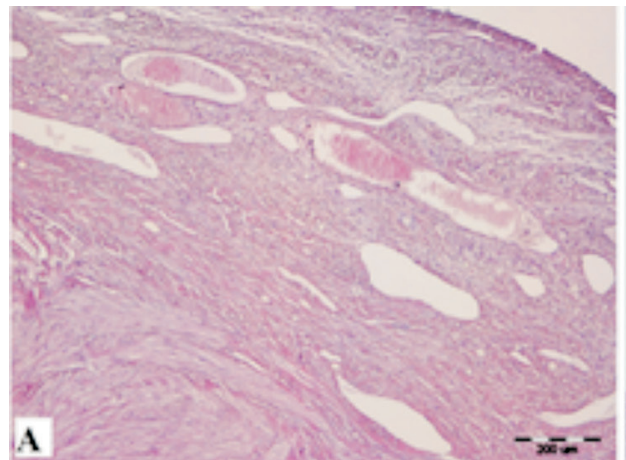

Fig. 3A. Extensive fibrosis of the cortex of the left ovary of female No. 3. Scale bar $=$ $200 \mu \mathrm{m}, \mathrm{H} \& \mathrm{E}, \times 20$.

\section{Discussion}

Earliest ovarian activity. The ovaries of both young females in this study represented typical ovaries of reproductively mature female animals, although they were at the ages of 2 years and 2 or 4 months (in their $3^{\text {rd }}$ year of life). SCHWARTZ et al. (2003b) documented overall mean ages of primiparity for wild North American brown bear populations, which averaged 6.3 years for interior and 6.4 years for coastal populations, with the earliest recorded births at 4.4 years. AUNE et al. (1994) concluded that female grizzly bears commonly conceive when they are 4 years old and produce a litter at 5 years of age, with two records of 3 -year-old bears breeding in the spring and conceiving to produce
Fig. 2B. Corpus luteum in the right ovary of female No. 2 (arrows) measuring 1582 x 980 $\mu \mathrm{m}$. Scale bar $=1000 \mu \mathrm{m}, \mathrm{H} \& \mathrm{E}, \times 4$. Inset: Higher magnification of lutein cells. Scale bar:

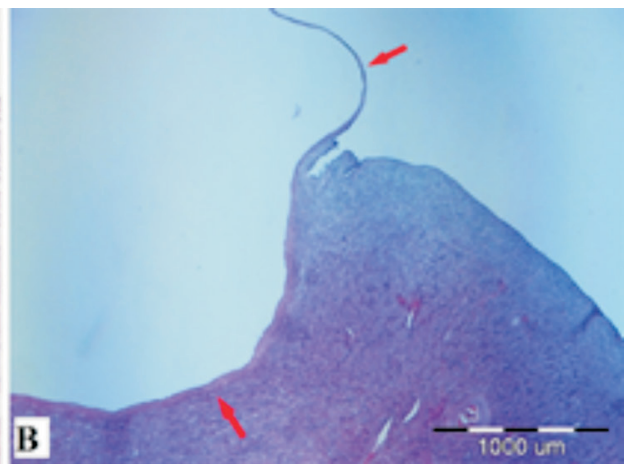

Fig. 3B. Cortical area of the right ovary of female No. 4 containing one cystic subsurface epithelial structure (SES; arrows) lined by flat epithelial cells. Scale bar $=1000 \mu \mathrm{m}$. H\&E, $\times 4$. 


\section{S. Reljić et al.: Reproductive span in captive brown bears}

a litter at 4 years of age. In Europe, SWENSON et al. (2001) reported that the mean ages of primiparity in wild brown bears are 4.5 years and 5.4 years in south-central and northern Sweden, respectively, with a correlation of the beginning of reproduction with adult female body mass (SWENSON et al., 2007). In our study, the age of the beginning of reproduction was lower than the reported age in SWENSON et al., 2001, but our research included only captive bears.

In wild populations of American black bears (Ursus americanus), polar bears (Ursus maritimus) and American brown bears (Ursus arctos horribilis) the influence of the nutritional condition of females has been reported to influence the age of their first birth. Further, it has been proven that the age of primiparity in black bears is nutritionally influenced and a weight-dependent parameter (NOYCE and GARSHELIS, 1994), and that food quality and abundance causes regional variations in the age of primiparity (VITALE, 2015). American black bear females that fed on anthropogenic sources ("panhandler" bears) had a lower average minimum age of primiparity than that of wild females $(3.5$ and 4.2, respectively; McLEAN and PELTON, 1990). Captive bears living on a rich diet develop more rapidly than wild ones (reviewed in ZEDROSSER et al., 2004), which probably explains the early onset of reproductive changes in the ovaries in the current study.

There is evidence that in most domestic mammals (NOAKES, 2009), as well as in humans and rats (FRISCH, 1984), the onset of puberty is closely linked to the attainment of a critical body mass, as well as a minimum percentage of body fat or metabolic mass. Namely, the protein leptin, secreted by white fat cells in adipose tissue, serves as a permissive signal that enables puberty to occur (BARB and KRAELING, 2004). As circulating leptin concentrations reach a putative stimulatory threshold, it permits activation of the hypothalamic-pituitary-gonadal axis and the start of ovarian activity (PRVANOVIĆ BABIĆ et al., 2011). Data on body fat index or leptin concentration were not available for the bears in our study, but we assumed that the bears had abundant feed, leading to a higher body mass, attained earlier, and thus the early onset of reproduction.

STØEN et al. (2006) concluded that socially induced reproductive suppression and delay of primiparity in young, free-living brown bear females was due to resource competition within female hierarchies. The average age of primiparity was 4.3 years in females that dispersed outside their mother's home range, and 5.2 years in philopatric females. Also, a negative correlation has been found between the age of sexual maturity in grizzly bears and latitude (STRINGHAM, 1984; AUNE et al., 1994) - the higher the latitudes, the later the age of sexual maturity. The young female bears in our study lived at low latitudes, with no contact with other female bears, therefore achieving sexual maturity at an early age. 
We emphasise the finding of "mature" corpus luteum in the ovary of female No. 2 as clear evidence of ovulation and previous mating. Immediately after ovulation, the formation of the corpus haemorrhagicum in most species of domestic mammals develops into a so-called immature corpus luteum in approximately $72 \mathrm{~h}$, which continues to a mature corpus luteum approximately $150 \mathrm{~h}$ after ovulation. The mature corpus luteum remains with the ovary until luteolysis takes part (NOAKES, 2009). Ovariectomy on female No. 2 was performed on May 16, 2012 so we may conclude that at least one coitus with subsequent ovulation took place a minimum of about six days before, which corresponds to the mating season in free-living brown bears in Croatia (HUBER et al., 2008) and elsewhere in the world (STEYAERT et al., 2012). To the authors' knowledge, this is the earliest recorded and histologically demonstrated ovulation in captive brown bears. This corresponds to the earliest reported signs of ovulation and successful reproduction a year later in free-living brown bear females (TSUBOTA et al., 1989; ZEDROSSER et al., 2004; FRKOVIC et al., 2001).

We assumed certain similarities in food availability between wildlife supplementary feeding and diet in captive conditions. Hence, we made a short appraisal of the possible contribution of supplementary feeding on earlier maturity in free-living brown bear females, and its effect on population dynamics. Free-living brown bears in many countries have the opportunity to utilise supplemental anthropogenic food sources at feeding sites (exposed for bears, as well as for other wildlife) to a great extent (KAVČIČ et al., 2015; ZEDROSSER et al., 2004). The early primiparity in Austrian brown bears occurred in a population with year-round access to cereals at deer feeding stations (ZEDROSSER et al., 2004). In mammals, body mass is positively correlated with female survival, juvenile recruitment and litter size, as well as population dynamics (ZEDROSSER et al., 2013). Hence, the earlier primiparity that may occur in free-living bears due to supplemental feeding would have importance for intensified population growth. According to population matrix modelling (RELJIĆ et al., 2018), females in the third year of life represent about $6.6 \%$ of the total number of females in the Croatian brown bear population.

Senescence process and post-reproductive phase. At a certain age, female reproductive capability decreases due to senescence processes. As explained by CARNEVALE (2008), an age-associated decrease in fertility and cyclic activity occurs in the second half of the expected lifespan in women and mares. In senescent female rats, profound alterations in the neuroendocrine axis were documented by substantially reduced GnRH neurons and LH surge attenuation (GORE et al., 2000). Female brown bears have a lower rate of fertility, by $7.5 \%$, after the age of 16 years and it decreases further with age (SCHWARTZ et al., 2003a). The findings of ovarian atrophy and multiple SES cysts are frequent in geriatric female dogs and cats (MacLACHLAN and KENNEDY, 2002). The same alterations found in this study indicate that the ovaries of brown bears share similar degenerative and proliferative patterns with domestic canids, and these could be recognised as ageing 


\section{S. Reljić et al.: Reproductive span in captive brown bears}

changes in the two old brown bear females from this study as well. However, both the older females were chronically ill, which could affect the activity of ovaries in these females, and therefore these results may not reflect the actual status of ovarian activity in healthy old females.

Evolutionary pressure selects towards maximising the reproductive effort and minimising the post-reproductive phase (NISHIDA et al., 2003; CHARNOV, 2004; REZNICK et al., 2006). According to a review by STEYAERT et al. (2012) no female bear older than 29 years has given birth. We reported similarly late litters at 26 and 28 years of age, but also eight years of life after the end of the reproductive activity. This range of post-reproductive phase in captive conditions may be much wider than in freeliving animals (SCHWARTZ et al., 2003a).

\section{Conclusions}

Histological examination of the ovaries of younger animals revealed the presence of primordial, primary, secondary and tertiary follicles within the ovarian cortex. These findings represent typical ovaries of reproductively mature female animals, although they were at the ages of 2 years and 2 or 4 months (in their $3^{\text {rd }}$ year of life).

The finding of the "mature" corpus luteum in the ovary of female No. 2 indicated clear evidence of recent ovulation and previous mating. To our knowledge, this is the first histological proof of the earliest age of ovulation recorded for captive brown bears.

Ovarian atrophy and severe fibrosis of the cortex and medulla of both females' ovaries, accompanied by the development of multiple cystic SES in the case of the older bears in this study, indicates that the ovaries of brown bears share similar degenerative and proliferative senescence-related patterns with domestic canids.

The oldest female had records of successful births at the ages of 26 and 28 years. Both recorded birth events represent one of the latest confirmed occurrences of successful ovulation, conception and birth amongst brown bears.

\footnotetext{
Acknowledgements

We thank Piotr Kierzkowski for the high quality macroscopic and microscopic pictures of the ovaries of female No. 4. We thank the Royal Society for Prevention of Cruelty to Animals (RSPCA) and the city of Braniewo for funding and help in carrying out the detailed examination and diagnosis of bears kept in Braniewo Zoo, where the samples from female No. 4 were obtained, and the bear keepers for their valuable support during the procedures. The authors are thankful to Ivan Pavenka Crnković from Kuterevo Bear Sanctuary for collaboration during ovariectomy procedures on females No. 1 and 2.

The work was supported by the European Commission under the FP7 "HUNTing for Sustainability" and LIFE+ "LIFE DINALP BEAR" projects. Neither the European Commission nor any person acting on behalf of the Commission is responsible for the use made of the information. The views expressed in this publication are the sole responsibility of the authors and do not necessarily reflect the views of the European Commission. Additionally, the work was funded by the Research Council of Norway, grant number ES459363 and EURONATUR projects.
} 
S. Reljić et al.: Reproductive span in captive brown bears

\section{References}

AUNE, K. E., R. D. MACE, D. W. CARNEY (1994): The reproductive biology of female grizzly bears in the Northern Continental Divide Ecosystem with supplemental data from the Yellowstone ecosystem. Int. Conf. Bear Res. and Manage. 9, 451-458.

DOI: $10.2307 / 3872732$

BARB, C. R., R. R. KRAELING (2004): Role of leptin in the regulation of gonadotropin secretion in farm animals. Anim. Reprod. Sci. 82-83, 155-167.

DOI: $10.1016 /$ j.anireprosci.2004.04.032

BEN-DAVID, M., K. TITUS, L. R. BEIER (2004): Consumption of salmon by Alaskan brown bears: a trade-off between nutritional requirements and the risk of infanticide? Oecologia 138, 465-474.

DOI: $10.1007 / \mathrm{s} 00442-003-1442-\mathrm{x}$

BERGA, S. L. (2008): Stress and reproduction: a tale of false dichotomy? Endocrinology 149, 867-868.

DOI: $10.1210 /$ en.2008-0004

BOONE, W. R., J. C. CATLIN, K. J. CASEY, E. T. BOONE, P. S. DYE, R. J. SCHUETT, J. O. ROSENBERG, T. TSUBOTA, J. M. BAHR (1998): Bears as induced ovulators: a preliminary study. Ursus 10, 503-505.

BOONE, W. R., B. B. KECK, J. C. CATLIN, K. J. CASEY, E. T. BOONE, P. S. DYE, R. J. SCHUETT, J. O. ROSENBERG, T. TSUBOTA, J. M. BAHR (2004): Evidence that bears as induced ovulators. Theriogenology 61, 1163-1169.

DOI: 10.1016/j.theriogenology.2003.07.016

CARNEVALE, E. M. (2008): The mare model for follicular maturation and reproductive ageing in the woman. Theriogenology 69, 23-30.

DOI: 10.1016/j.theriogenology.2007.09.011

CHARNOV, E. L. (2004): The optimal balance between growth rate and survival in mammals. Evol. Ecol. Res. 6, 307-313.

DAHLE, B., J. E. SWENSON (2003): Seasonal range size in relation to reproductive strategies in brown bears Ursus arctos. J. Anim. Ecol. 72, 660-667.

DOI: 10.1046/j.1365-2656.2003.00737.x

EGBERT, A. L., A. W. STOKES (1974): The social behaviour of brown bears on an Alaskan salmon stream. Int. Conf. Bear Res. and Manage. 3, 41-56.

DOI: $10.2307 / 3872753$

FRISCH R. E. (1984): Body fat, puberty and fertility. Biological Reviews 59, 161-188.

DOI: $10.1111 / j .1469-185 x .1984 . t b 00406 . x$

FRKOVIC, A., D. HUBER, J. KUSAK (2001): Brown bear litter sizes in Croatia. Ursus 12, 103-106. 


\section{S. Reljić et al.: Reproductive span in captive brown bears}

GORE, A. C., T. OUNG, S. YUNG, R. A. FLAGG, M. J. WOLLER (2000): Neuroendocrine mechanisms for reproductive senescence in the female rat: Gonadotropin-releasing hormone neurons. Endocrine 13, 315-323.

DOI: $10.1385 /$ endo:13:3:315

HERRERO, S. (1983): Social behaviour of black bears at a garbage dump in Jasper National Park. Int. Conf. Bear Res. and Manage. 5, 54-70.

DOI: $10.2307 / 3872520$

HUBER, Đ., Z. JAKŠIĆ, A. FRKOVIĆ, Ž. ŠTAHAN, J. KUSAK, D. MAJNARIĆ, M. GRUBEŠIĆ, B. KULIĆ, M. SINDIČIĆ, A. MAJIĆ SKRBINŠEK, V. LAY, M. LJUŠTINA, D. ZEC, R. LAGINJA, I. FRANCETIĆ (2008): Brown Bear Management Plan for the Republic of Croatia. Ministry of Regional Development, Forestry and Water Management, Directorate for Hunting and Ministry of Culture, Directorate for the Protection of Nature. Zagreb, p. 92 (in Croatian).

KAVČIČ, I., M. ADAMIČ, P. KACZENSKY, M. KROFEL, M. KOBAL, K. JERINA (2015): Fast food bears: brown bear diet in a human-dominated landscape with intensive supplemental feeding. Wildlife Biol. 21, 1-8.

DOI: $10.2981 /$ wlb.00013

KIRBY, E., A. C. GERAGHTY, T. UBUKA, G. E. BENTLEY, D. KAUFER (2009): Stress increases putative gonadotropin inhibitory hormone and decreases luteinizing hormone in male rats. Proceedings of the National Academy of Sciences of the United States of America 106, 11324-9.

DOI: 10.1073 /pnas.0901176106

KIRKWOOD, T. B. L., M. R. ROSE (1991): Evolution of senescence: late survival sacrificed for reproduction. Philos. Trans. R. Soc. Lond. B. Biol. Sci. 332, 15-24.

DOI: $10.1098 /$ rstb.1991.0028

KOENE, P. (1996): Bear behaviour in large enclosures. In: Large Bear Enclosures. (Koene, P., Ed.). International Bear Foundation, Rhenen, pp. 43-50.

KNOTT, E. J., N. BUNNEFELD, D. HUBER, S. RELJĆ, V. KEREŽI, E. J. MILNER-GULLAND (2014): The potential impacts of changes in bear hunting policy for hunting organisations in Croatia. Eur. J. Wildl. Res. 60, 85-97.

DOI: $10.1007 / \mathrm{s} 10344-013-0754-3$

MacLACHLAN, N. J., P. C. KENNEDY (2002): Tumors of the genital system. In: Tumors in Domestic Animals (Meuten, D. J., Ed.), Iowa State Press, pp. 547-573.

DOI: $10.1002 / 9780470376928$

McLEAN, P. K., M. R. PELTON (1990): Some demographic comparisons of wild and panhandler bears in the Smoky Mountain. Int. Conf. Bear Res. and Manage 8, 105-112.

DOI: $10.2307 / 3872908$

NISHIDA, T., N. CORP, M. HAMAI, T. HASEGAWA, M. HIRAIWA-HASEGAWA, K. HOSAKA, K. D. HUNT, N. ITOH, K. KAWANAKA, A. MATSUMOTO-ODA, J. C. MITANI, M. NAKAMURA, K. NORIKOSHI, T. SAKAMAKI, L. TURNER, S. UEHARA, K. ZAMMA 
S. Reljić et al.: Reproductive span in captive brown bears

(2003): Demography, female life history, and reproductive profiles among the chimpanzees of Mahale. Am. J. Primatol. 59, 99-121.

DOI: 10.1002/ajp.10068

NOAKES, D. E. (2009): Normal cyclical ovarian activity and its control - Endogenous and exogenous control of ovarian cyclicity. In: Veterinary Reproduction and Obstetrics (Noakes, D. E., T. J. Parkinson, G. C. W. England, Eds.), $9^{\text {th }}$ ed., Saunders, England, UK, pp. 3-61.

NOYCE, K. V., D. L. GARSHELIS (1994): Body size and blood characteristics as indicators of condition and reproductive performance in black bears. Int. Conf. Bear Res. Manage 9, 481-496.

DOI: $10.2307 / 3872736$

PECCEI, J. S (2001): A critique of the grandmother hypotheses: old and new. Am. J. Hum. Biol. $13,434-452$.

DOI: 10.1002/ajhb.1076

PRVANOVIĆ BABIĆ, N., B. RADIŠIĆ, M. LIPAR, I. MAJIĆ BALIĆ, A. ORAK, M. SAMARDŽIJA, N. MAĆEŠIĆ, T. KARADJOLE, G. BAČIĆ, M. CERGOLJ (2011) Influence of lameness-caused stress, pain and inflammation on health and reproduction in HolsteinFrisian bulls. Vet. stanica, Supplement 1, Book of Proceedings. Zagreb, Croatia. pp. 3-6 (in Croatian).

RADISIC, B., M. SINDICIC, D. HUBER, J. KUSAK, T. GOMERCIC, D. VNUK, D. MATICIC, A. SLAVICA (2010): Ovariectomy of a brown bear (Ursus arctos): a case report. Vet. Med. (Praha) 55, 353-357.

DOI: $10.17221 / 2965$-vetmed

RELJIC, S., K. JERINA, E. B. NILSEN, D. HUBER, J. KUSAK, M. JONOZOVIC, J. D. C. LINNELL (2018): Challenges for transboundary management of a European brown bear population. Glob. Ecol. Conserv. 16, e00488

DOI: 10.1016/j.gecco.2018.e00488

REZNICK, D., M. BRYANT, D. HOLMES (2006): The Evolution of Senescence and PostReproductive Lifespan in Guppies (Poecilia reticulata). PLoS Biol

DOI: 10.1371/journal.pbio.0040007

SENGER, P. L. (2015): Puberty. In: Pathways to Pregnancy \& Parturition, $3^{\text {th }}$ ed., Current Conceptions. Inc., Redmond, OR, USA, pp. 128-146.

SCHLAFER, D. H., R. A. FOSTER (2016): Ovarian cysts - female genital system. In: Jubb, Kennedy and Palmer's Pathology of Domestic Animals, Vol. 3, $6^{\text {th }}$ ed. (Grant Maxie, M., Ed.), Elsevier, St. Louis, pp. 371-372.

DOI: 10.1016/b978-0-7020-5319-1.00015-3

SCHWARTZ, C. C., K. A. KEATING, H. V. REYNOLDS, V. G. JR. BARNES, R. A. SELLERS, J. E. SWENSON, S. D. MILLER, B. N. McLELLAN, J. KEAY, R. McCANN, M. GIBEAU, W. F. WAKKINEN, R. D. MACE, W. KASWORM, R. SMITH, S. HERRERO (2003a): Reproductive maturation and senescence in the female brown bear. Ursus 14, 109-119. 
S. Reljić et al.: Reproductive span in captive brown bears

SCHWARTZ, C. C., S. D. MILLER, M. A. HAROLDSON (2003b): Grizzly bear. In Wild Mammals of North America: Biology, Management, and Conservation (Feldhamer, G. A., B. C. Thompson, J. A. Chapman, Eds.). $2^{\text {nd }}$ ed., Johns Hopkins University Press, Baltimore, Maryland. USA. pp. 556-586.

STEYAERT, S. M. J. G., A. ENDRESTØL, K. HACKLÄNDER, J. E. SWENSON, A. ZEDROSSER (2012): The mating system of the brown bear Ursus arctos. Mammal Rev. 42, 12-34.

DOI: 10.1111/j.1365-2907.2011.00184.x

STIRLING, I., A. E. DEROCHER (1990): Factors affecting the evolution and behavioural ecology of the modern bears. Int. Conf. Bear Res. and Manage. 8, 189-204.

DOI: $10.2307 / 3872919$

STØEN, O. G., A. ZEDROSSER, P. WEGGE, J. E. SWENSON (2006): Socially induced delayed primiparity in brown bears Ursus arctos. Behav. Ecol. Sociobiol. 61, 1-8.

DOI: $10.1007 / \mathrm{s} 00265-006-0231-\mathrm{Z}$

STRINGHAM, S. F. (1984): Responses by grizzly bear population dynamics to certain environmental and biosocial factors. PhD Thesis, University of Tennessee, Knoxville, USA. 464 pp.

SWENSON, J. E., F. SANDEGREN, S. BRUNBERG, P. SEGERSTROM (2001): Factors associated with loss of brown bear cubs in Sweden. Ursus 12, 69-80.

SWENSON, J. E., M. ADAMIC, D. HUBER, S. STOKKE (2007): Brown bear body mass and growth in northern and southern Europe. Oecologia 153, 37-47.

DOI: $10.1007 /$ s00442-007-0715-1

TEISBERG, J. E., M. A. HAROLDSON, C. C. SCHWARTZ, K. A. GUNTHER, J. K. FORTIN, C. T. ROBBINS (2014): Contrasting past and current numbers of bears visiting Yellowstone cutthroat trout streams. J. Wildl. Manage 78, 369-378.

DOI: $10.1002 /$ jwmg. 667

TSUBOTA, T., H. KANAGAWA, T. MANO, T. AOI (1989): Corpora albicantia and placental scars in the Hokkaido brown bear. In: Bears - Their Biology and Management. (Darling, L. M., W. R. Archibald, Eds.) Proceedings of the Int. Conf. Bear Res. and Manage. 8, 125-128.

DOI: $10.2307 / 3872910$

TSUBOTA, T., M. SATO, T. OKANO, S. NAKAMURA, M. ASANO, T. KOMATSU, H. SHIBATA, M. SAITO (2008): Annual changes in serum leptin concentration in the adult female Japanese Black Bear (Ursus thibetanus japonicus). J. Vet. Med. Sci. 70, 1399-1403.

DOI: $10.1292 /$ jvms. 70.1399

VITALE, A. A. (2015): Reproductive Ecology of Black Bears in Maine: Maternal Effect, Philopatry, and Primiparity. MSc Thesis, University of Maine, Orono, USA. 78.

DOI: digitalcommons.library.umaine.edu/etd/2305

WHITE, D. JR., J. G. BERARDINELLI, K. E. AUNE (2005): Seasonal differences in spermatogenesis, testicular mass and serum testosterone concentrations in the grizzly bear. Ursus 16, 198-207.

DOI: 10.2192/1537-6176(2005)016[0198:sdistm]2.0.co;2

Vet. arhiv 89 (2), 233-246, 2019 
S. Reljić et al.: Reproductive span in captive brown bears

WILLIAMS, G. C. (1957): Pleiotropy, natural selection, and the evolution of senescence. Evolution $11,398-411$.

DOI: $10.2307 / 2406060$

YAMANAKA, A., K. YAMAUCHI, T. TSUJIMOTO, T. OI, T. MIZOGUCHI, S. SAWADA, M. SHIMOZURU, T. TSUBOTA (2011): Estimating the success rate of ovulation and early litter loss rate in the Japanese black bear (Ursus thibetanus japonicus) by examining the ovaries and uteri. Jap. J. Vet. Res. 59, 31-39.

DOI: $10.14943 /$ jjvr.59.1.31-39

ZEDROSSER, A., G. RAUER, L. KRUCKENHAUSER (2004): Early primiparity in brown bears. Acta Theriol. 49, 427-432.

DOI: $10.1007 / \mathrm{bf} 03192540$

ZEDROSSER, A., F. PELlETIER, R. BISCHOF, M. FESTA-BIANCHET, J. E. SWENSON (2013): Determinants of lifetime reproduction in female brown bears: early body mass, longevity, and hunting regulations. Ecology 94, 231-240.

DOI: $10.1890 / 12-0229.1$

Received: 31 August 2018

Accepted: 21 January 2019

\section{RELJIĆ, S., A. SERGIEL, N. PRVANOVIĆ BABIĆ, A. BECK, S. KUŽIR, B. RADIŠIC, R. MAŚLAK, M. BEDNARSKI, T. PIASECKI, D. HUBER, Đ. HUBER: Utvrđivanje raspona dobi i reproduktivne aktivnosti smeđih medvjedica (Ursus arctos) iz zatočeništva pomoću morfohistološke pretrage jajnika - kratko priopćenje. Vet. arhiv 89, 233-246, 2019. \\ SAŽETAK}

Cilj istraživanja bio je pregledom građe jajnika utvrditi raspon dobi i reproduktivne aktivnosti u mladih i starih ženki smeđega medvjeda (Ursus arctos) iz zatočeništva. Jajnici su dobiveni ovariektomijom dviju dvogodišnjih ženki i tijekom razudbe 31-godišnje te 36-godišnje ženke. Svi su jajnici pregledani makroskopski i histološki. Histološkom pretragom u mladih su životinja u kori jajnika otkriveni primordijalni, primarni, sekundarni i tercijarni folikuli. U jednom je jajniku dokazano zrelo žuto tijelo (corpus luteum), pokazatelj nedavne ovulacije što je, prema nama dostupnim podacima, prvi zabilježen histološki dokaz najranije ovulacije u smeđih medvjeda u zatočeništvu. Atrofija jajnika povezana sa starenjem i praćena razvojem multiplih cističnih supseroznih epitelnih struktura (SES) u starih medvjeda u ovom istraživanju upućuje na to da se u smeđih medvjeda pojavljuju slične degenerativne i proliferativne promjene kao i u domaćih kanida. Najstarija ženka imala je zabilježene uspješne porođaje u dobi od 26 i 28 godina. Oba porođaja pripadaju najkasnijim potvrđenim pojavama uspješne ovulacije, začeća i porođaja u smeđih medvjeda.

Ključne riječi: reprodukcija; pubertet; ovulacija, žuto tijelo; postreproduktivna faza 